\title{
earchOnline@JCU
}

This is the Accepted Version of a paper published in the journal: Marketing Intelligence and Planning

Eagle, L.C., and Dahl, S. (2016) Empowering or misleading? Online health information provision challenges. Marketing Intelligence and Planning, 34 (7). pp. 1000-1020

http://dx.doi.org/10.1108/MIP-07-2015-0127 


\section{Empowering or misleading? Online Health Information Provision Challenges}

\section{Structured Abstract}

Purpose - Patient empowerment (PE) is a key public health policy tool globally which is seen as unproblematic, but contains a number of unwarranted assumptions and unrecognised challenges to achieving effective implementation. Further, the theoretical foundations for understanding the impact of persuasive health communications on PE are weak. The purpose of this paper is to review these factors and to highlight major areas of concern.

Design - Firstly, the assumptions underpinning empowerment and the implicit theoretical foundations for active health information seeking behaviours are reviewed. This is then followed by a readability analysis of Internet-based material relating to two general medical conditions, four chronic medical conditions and six patient information leaflets which was conducted to explore issues relation to the provision and readability of online health information.

Findings - The assumptions underpinning expectations of policy makers and health organisations regarding active health information seeking are shown to be problematic, with several potential impediments to effective PE implementation, including the fact that almost all of the online material reviewed is written in language too complex for the majority of the general public to comprehend, let alone act on.

Practical Implications -Recommendations are made for guiding information seeking and a research agenda is outlined that would aid in strengthening theoretical underpinnings, expand knowledge and thereby help inform practice and policy debate regarding how patient empowerment can be improved.

Originality / value - This paper contributes to understanding of the challenges of effective health communication in the digital age by highlighting the need for a greater understanding of online health information seeking and the impact of limited health literacy and numeracy.

Key words: DTC, DTCA, health information seeking, health literacy, digital literacy

Article Classification: Research paper 


\section{Introduction}

Patient empowerment (PE) to make decisions regarding medical treatments and the management of chronic medical conditions is a cornerstone of a patient-centred approach to healthcare that began in the 1990s (Feste \& Anderson, 1995). However, after two decades, there appears to still be a lack of understanding of the drivers of, and barriers to, PE (Prigge, Dietz, Homburg, Hoyer, \& Burton, 2015). Given the 'surfeit of health information from commercial and non-commercial sources' (Reyna, Nelson, Han, \& Dieckmann, 2009, p. 943), particularly from online sources, this paper therefore aims to review the theoretical assumptions behind PE and to explore the type and characteristics of online health information available, identifying areas of concern for PE implementation.

The World Health Organisation supports involvement of healthcare system users in decision making, and patients' influence rights have been strengthened in several countries (Joosten et al., 2008). The concept of active information seeking patients who are empowered to effectively manage their general health and well-being or chronic medical conditions (Black et al., 2011) needs to be viewed in a holistic manner, incorporating medical professionalT support for, or resistance to PE and an understanding of all sources of potential information together with an analysis of how information from different sources is integrated and used in decision making under different levels of certainty regarding potential outcomes (Politi, Han, $\&$ Col, 2007).

Theories used in this sector should enable analysis of these issues and the prediction of the relative influence of different factors on PE. However we will show that current theoretical foundations are weak and require considerable development.

\section{Literature Review}

\section{Theoretical Models}

Two theoretical concepts may explain patient information-seeking behaviours, particularly in the online environment. Uses and Gratification Theory suggests that people actively seek out information from specific media such as the internet to satisfy specific needs or achieve specific goals which may extend beyond information to encompass social and psychological needs (Hou \& Shim, 2010). Unsatisfactory doctor-patient communications is a known predictor of post-consultation online information seeking (Li, Orrange, Kravitz, \& Bell, 2014; Tustin, 2010), however the motivations for, and extent of online searches pre-consultation is not as well understood. While better knowledge of health issues prior to a consultation with a doctor is claimed to result in more productive visits (Lee, 2008), this appears to be dependent on the patient's ability to identify accurate and relevant information and to be able to relate it to their own personal situation. The readability analyses reported later in this paper will show that there are significant potential problems with this.

Doctors may view patients who have accessed online information pre-consultation as a burden due to the time needed to evaluate the information, correct misconceptions and modify unrealistic patient expectations, even if patients themselves feel empowered by their prior information gathering (Massey, 2013; Tustin, 2010). Consistent with the concept of Media Systems Dependency, online resources may be seen as more accessible than health professionals and the more they are used, the more dependent people become on them (Tustin, 2010). Thus Uses and Gratification Theory indicates that patients with unmet needs will seek alternative information sources; this seems most likely when anxieties are high and it is felt that questions have not been answered during a consultation (Bell, Hu, Orrange, \& Kravitz, 2011). Media Systems Dependency offers an explanation for a perception among 
patients that online sources enable more information to be accessed than is possible within a tightly time-constrained consultation; satisfaction with initial searchers will lead to increased reliance on those sources. (Bowes, Stevenson, Ahluwalia, \& Murray, 2012). However, if information is not available in a form patients can access, understand and apply, patient empowerment will be hampered, with negative consequences for both patient well-being and health system costs.

The weaknesses of the two concepts are that, while they offer broad descriptive facilities, they do not offer predictive capacity. It is likely that there are diverse patient segments with differing information acquisition strategies and resulting outcomes (Acosta-Deprez et al., 2013; Prigge et al., 2015). There is thus a clear need to understand the use of digital media such as the Internet as a health information source across patient segments and to understand the consequences, both positive and negative, of information seeking behaviours using such sources for both the patient and the medical practitioner. From this understanding, strategies to help medical practitioners respond effectively to patients who have gathered online health information can be developed. By strengthening theoretical underpinnings of this activity, strategies for maximising benefits and minimising potential negative impacts, guidance for policy decisions aimed at improving efficient and effective use of all resources can be achieved.

\section{Active and Empowered Patients and Electronic Information}

While enthusiastic support for the use of electronic technology to communicate health-related information is evident (Joosten et al., 2008), risks associated with this strategy are generally not recognized and the cost-effectiveness of programs using electronic communications platforms has yet to be demonstrated (Black et al., 2011). Support is largely due to a growing, but not universal, acceptance of active partnerships, as opposed to earlier paternalistic relationships between medical professionals and patients (Hou \& Shim, 2010). While some doctors appear to welcome active information seeking by patients as leading to more productive consultations, others are reported as feeling their expertise is devalued and that they have lost control of information provision (Hughes, Joshi, \& Wareham, 2008). Negative reception of patient-sourced information may lead to avoidance of the doctor in future and increased searching for information and other opinions (Bowes et al., 2012). Statement such as 'patients should be more active and effective managers of their health'(J. Greene \& Hibbard, 2012, p. 520) appears to have been accepted uncritically: there is a growing body of literature relating to patient empowerment (see, for example, Schulz \& Nakamoto, 2013b) and patient activation whereby patients 'have the motivation, knowledge, skills and confidence to make effective decisions to manage their health' (J. Greene \& Hibbard, 2012). While empowerment is growing in popularity as a concept, how it can be most effectively achieved remains under-researched (Calvillo, Román, \& Roa, 2013), with statements such as patients being 'properly informed' by doctors open to interpretation and offering little guidance to processes or measurement. An implicit assumption behind PE is that it is unproblematic and medical professionals operationalize it. The impact of support for, versus resistance to, active patient involvement in treatment decisions remains under researched.

Empowerment must also be viewed in the context of patients seeking information independent of medical professionals. 'More people are posing health questions to google than to their doctors' (Kitchens, Harle, \& Li, 2014, p. 454). Almost half of those accessing Internet-based information do not discuss the information obtained with their doctor, although this drops to less than $20 \%$ for chronic conditions (Bartlett \& Coulson, 2011). If the 
information obtained is high quality, people should be better informed and make better health-related decisions. Conversely, low quality information may expose people to inaccurate or emotionally disturbing material, or lead to unnecessary or unwise health treatments (Hu, Bell, Kravitz, \& Orrange, 2012). It is suggested that increased reliance on the Internet to disseminate health information will disadvantage some sections of the population due to a lack of ability to access, understand and effectively apply information (Bodie \& Dutta, 2008; Kaphingst et al., 2012). Health literacy and the related concept of health numeracy are discussed in later sections, however while they are necessary for empowerment, they are not of themselves sufficient to achieve it: motivation and selfefficacy are also needed. Further, supporters of empowerment ignore the fact that not all patients want to be actively involved in medical decision (Lee, Gray, \& Lewis, 2010). There is thus a need to recognise that the expectation that patients will understand and apply healthrelated information may actually represent an unwelcome burden to some patients or their caregivers (Reyna et al., 2009). Organisations such as the WHO do not appear to have taken these issues into consideration in promoting the patient empowerment concept.

Another issue with the potential to adversely impact on patient empowerment is access to harmful information, particularly from online sources. Policy makers and health organisations appear to assume that all information available is of potential benefit to patients. Concerns re safety and ability to assess quality of online health information are noted in literature (Lau, Gabarron, Fernandez-Luque, \& Armayones, 2012), specifically regarding harmful health material targeted at consumers (e.g. pro-tobacco content in YouTube videos), public displays of unhealthy behaviours (e.g. self-harm and drug use), tainted public health messages (content counter to official public health messages), and psychological impacts from accessing inappropriate social media content (exposure to disturbing or offensive material without warning). Neither of the two theoretical models reviewed earlier offer adequate explanatory or predictive capacity to encompass the impact of positive versus negative relationships with medical professionals or access to information of dubious quality or value. Given the increasing use of online information sources, we therefore turn our attention to different sources of online health information, commencing with information from commercial sources.

\section{Direct to Consumer Promotion of Medication}

DTC involves the promotion of medication direct to the consumer, including advertising (DTCA) and other forms of promotional activity. It is particularly controversial in relation to prescription medicines as the promotion is to the patient, but the prescribing decision rests with a medical professional. Debate has raged for well over a decade regarding its effect on doctor-patient relationships, prescribing practices and patient outcomes (Eagle \& Chamberlain, 2004). In 2010, the overall expenditure on prescription medicines was estimated at US\$307 billion (Fogel \& Teichman, 2014). It is difficult to determine expenditure on direct-to-consumer advertising of prescription medications: within the USA it was estimated at US\$4.8 billion in 2008 (Ahn, Park, \& Haley, 2014) but this figure does not include precise expenditure on digital media, which some estimate to be $4 \%$ of overall expenditure (J. A. Greene \& Kesselheim, 2010).

There are concerns that DTCA activity may be 'hidden within disease awareness campaigns, ePharmacy web pages and online communities' (Gu, Williams, Aslani, \& Chaar, 2011, p. 196) making expenditure estimates challenging. While direct-to-consumer advertising (DTC) of prescription medication is only formally permitted in the USA and New Zealand, electronic forms of DTC (e-DTC) enable consumers from other countries to access DTC 
material, including websites, advertisements and social media sites (Ahn et al., 2014; Choi \& Lee, 2007; Donohue, Cevasco, \& Rosenthal, 2007; Kornfield, Donohue, Berndt, \& Alexander, 2013). Specific concerns have been raised regarding the inadequacy of current DTC regulatory provisions regarding electronic/online DTC (eDTC) (Gibson, 2014). However, no research has been conducted specifically on eDTC's actual effects on patient information seeking behaviours and interactions with health professionals. The ten largest global pharmaceutical companies are all active on social media such as Facebook, Twitter and sponsored blogs with 8 also having YouTube channels (Collier, 2014).

In the two countries where DTC of prescription medicines is allowed, DTC in traditional media has been criticised as leading to increased financial burdens on the health system through 'disease mongering'(Kochen \& Córdoba, 2013, p. 27) or 'selling sickness' (Moynihan, Heath, \& Henry, 2002, p. 886). It is claimed that DTC fundamentally changes the doctor patient relationship (Spurgeon, 1999), including reports of patients requesting (McKinlay, Trachtenberg, Marceau, Katz, \& Fischer, 2014), or even insisting on being prescribed advertised medication (Mehta \& Purvis, 2003). 'Lifestyle medicines' (Gilbert, Walley, \& New, 2000, p. 1341), such as medicines for erectile dysfunctions, obesity, lipid lowering agents and proton pump inhibitors have been found to be advertised particularly heavily and requested frequently (Egger, Binns, \& Rossner, 2009).

Conversely, some positive effects of DTC have also been acknowledged, such as encouraging discussions with GPs about specific health problems (Finlayson, 2005) and increased patient confidence when talking about illnesses with a health care provider and actively seeking help (Myers, Royne, \& Deitz, 2011). There are several factors where different studies claim positive and negative impacts, leading to the observation that DTC 'is both beneficial and detrimental to the public health'(Ventola, 2011, p. 669). Table 1 summarises the main claims and counter claims made in the academic literature. The contradictory claims are largely due to problems in generalising from individual studies that focus on specific medication or medical conditions: there are likely to be multiple segments and multiple cost-benefit outcomes.

Table 1 Contradictory claims made in relation to the impact of DTC

\begin{tabular}{|c|c|}
\hline $\begin{array}{l}\text { Claim re positive effects (Ahn et al., 2014; } \\
\text { Ball, Liang, \& Lee, 2014; Donohue et al., } \\
\text { 2007; Liu \& Gupta, 2011) }\end{array}$ & $\begin{array}{l}\text { Claim re negative effects (Dave \& } \\
\text { Saffer, 2012; Gibson, 2014; Kornfield et } \\
\text { al., 2013) }\end{array}$ \\
\hline Averts under use of medications & $\begin{array}{l}\text { Consumers seek unnecessary drugs and } \\
\text { ignore alternative treatment options }\end{array}$ \\
\hline $\begin{array}{l}\text { Motivates consumers to actively interact with } \\
\text { doctors. Strengthens doctor-patient } \\
\text { relationships and adherence to prescribed } \\
\text { medication regimen }\end{array}$ & $\begin{array}{l}\text { Negatively impacts on doctor-patient } \\
\text { interactions and relationships, including } \\
\text { placing pressure on doctors to prescribe } \\
\text { specific medication }\end{array}$ \\
\hline $\begin{array}{l}\text { Improves acceptance of stigmatised health } \\
\text { conditions }\end{array}$ & $\begin{array}{l}\text { Increases stigma of conditions such as } \\
\text { mental illness }\end{array}$ \\
\hline $\begin{array}{l}\text { Encourages consumers to recognise } \\
\text { symptoms and seek medical advice }\end{array}$ & Leads to inaccurate self-diagnosis \\
\hline Educates and empowers & $\begin{array}{l}\text { Fails to provide balanced information of } \\
\text { range of treatments available, misinforms } \\
\text { and over-emphasises drug benefits }\end{array}$ \\
\hline $\begin{array}{l}\text { Encourages competition and lowers prices; } \\
\text { cost effective in terms of life-years saved }\end{array}$ & Inflates healthcare costs \\
\hline
\end{tabular}


Despite these contradicting findings and potential implications for health policy and communication regulation, there is, to date, relatively little research specifically addressing the extent and impact of online DTC (e-DTC), as an individual information source and its use in combination with other sources of medical information, given that online campaigns are accessible, though not regulated through traditional DTC-advertising regulations, globally. Again, the two theoretical models are inadequate to analyse or predict the impact of e-DTC on PE. We now focus on online information sources that are beyond the control of policy maker-related organisations, i.e. social media.

\section{Social Media}

Recent US studies suggest between $9 \%$ and $12 \%$ of people but almost $40 \%$ of patients with chronic diseases have participated in one or more of the over 12,000 online support groups available (Bartlett \& Coulson, 2011; Hu et al., 2012). Social media is claimed to raise awareness of health issues, improve access to information and empower individuals to manage their health. It also provides a platform for health interventions targeting populations that may otherwise be hard to reach (Mowlabocus, Harbottle, Dasgupta, \& Haslop, 2014). When dealing with specific medical conditions, social media may be used to locate others with similar conditions, thereby gaining support and a sense of belonging (Mano, 2014).While there are obvious benefits, there are also potential disadvantages. For example, misinterpretation of messages may occur and a lack of strong ties to other participants may mean that misunderstandings may not be corrected (Bartlett \& Coulson, 2011). Online discussion groups have been shown to lead to a 'nocebo' effect (Mao et al., 2013) where knowing of a side effect through reading online postings within virtual communities will likely make an individual attribute the side effect to a therapy, leading to discontinuation of, or refusal to commence medication. A further concern is that some social media sites have input from bloggers who appear to be independent but who are actually paid or sponsored by pharmaceutical companies (Gibson, 2014).

Thus, social media, like DTC, can be seen as having both positive and negative potential impacts. These can be summarized as follows (Table 2). Trust of Internet sourced material for health information has been shown unsurprisingly to predict online health information seeking (Miller \& Bell, 2012). The problem is not a lack of information but rather knowing what information to trust (Kravitz \& Bell, 2013) and being aware of potential negatives such as loss of privacy and Internet scams (Monteith, Glenn, \& Bauer, 2013). An 'abundance of health information does not always translate into informed choices' (Ivanitskaya, O'Boyle, \& Casey, 2006, p. 4) The most effective ways to integrate patient use of web-based information into health care practice and the role of medical professionals in guiding searches to relevant and credible sources is un-researched (Schulz \& Nakamoto, 2013a) as is the potential role of the pharmaceutical industry. In expanding existing theoretical models or developing new models, these factors must be explored and their influence incorporated. This will require sophisticated analytical techniques, such as structural equation modeling rather than purely descriptive techniques. 
Table 2 Benefits and limitations of using social media for health communication: general public and patients (Moorhead et al., 2013, pp. 35 -36)

\begin{tabular}{|l|l|}
\hline Benefits & Limitations \\
\hline $\begin{array}{l}\text { Increases interactions with others } \\
\text { information }\end{array}$ & Lack of reliability / quality concerns \\
\hline Increased accessibility and widening access & $\begin{array}{l}\text { Lack of confidentiality and privacy } \\
\text { disclosing personal information online }\end{array}$ \\
\hline Peer, social and emotional support & $\begin{array}{l}\text { Risks associated with communicating } \\
\text { harmful or incorrect advice using social } \\
\text { media }\end{array}$ \\
\hline Public health surveillance & Information overload \\
\hline Potential to influence health policy & $\begin{array}{l}\text { Not sure how to correctly apply information } \\
\text { found on line to personal health situation }\end{array}$ \\
\hline & $\begin{array}{l}\text { Certain social media technologies may be } \\
\text { more effective in behaviour change than } \\
\text { others }\end{array}$ \\
\hline & Adverse health consequences \\
\hline & Negative health behaviours \\
\hline
\end{tabular}

\section{Social Capital}

The social context of health information seeking and decision making, including social and cultural factors in individual homes, work environments (Nutbeam, 2008) and in the wider communities in which both of the former are situated has been under-researched and recent research suggests social capital may offer a useful framework for examining these influences. Social capital is 'actual or potential resources that result from social connections and senses of reciprocity and trust, which, when mobilised, can bring about outcomes at the individual and collective level' (Beaudoin \& Tao, 2007, p. 587). Interest in the concept within the health sector is relatively recent, but research has indicated that social capital can influence health outcomes as social networks enable information and resource sharing and support (Lewis \& Martinez, 2014). Close ties positively are associated with communication efficacy which then is associated with information seeking, however the relative impact of information from interpersonal versus mediated sources requires further investigation (Chen, Lee, Straubhaar, \& Spence, 2014; Lewis \& Martinez, 2014). While social capital is widely discussed, its precise meaning, dimensions and mechanisms are unclear. This is due, in part, to the fact that the concept is, in spite of a large body of literature on the subject, difficult to define due to multiple definitions stemming from disparate disciplinary approaches including economics, political science, sociology and anthropology and other social sciences. This diverse disciplinary interest has resulted in a lack of standardised measurement instruments (Gaag \& Webber, 2008) or empirical data across all aspects of society in which social capital (however defined) may have a role (Sabatini, 2009).

Social capital can be categorized into three subsets, bonding, bridging and linking. Bonding social capital focusses on homogeneous groupings, 'such as religious, cultural, professional, racial, or ethnic groups' (Ebi \& Semenza, 2008, p. 502): ties are generally close. Bridging social capital focusses on the connections between socially heterogeneous groups and linking social capital on the connections between people at different levels of power and influence although the latter is sometimes subsumed into bridging capital (Murayama, Fujiwara, \& 
Kawachi, 2012). While bridging ties may be weaker, they enable useful transfers of information (Lewis \& Martinez, 2014). Effective social capital enables a wider range of information sources and faster information flow and is linked to digital literacy and inequalities as social and digital connectivity are inter-related (Chen et al., 2014). Authors' comparison of effects across studies is hampered by inconsistent operationalization of the social capital construct. (Iwase et al., 2012).

Thus considerably more work will be required to determine how social capital can be conceptualised before it is able to be added to the range of other factors already noted as warranting inclusion in more powerful theoretical models that can explain and predict the impact of the increasingly complex range of factors potentially impacting effective $\mathrm{PE}$ implementation.

Some potential barriers to PE are more easily examined. We therefore now turn our attention to a fundamental barrier to patient empowerment, i.e. limitations within significant percentages of the population relating to access to information and its comprehension.

\section{Health Literacy, Numeracy, Digital Literacy and Digital Divides}

The percentage of the US population that seek health information online is at least $60 \%$ (Kitchens et al., 2014), and possibly over 70\% (Pew Research Internet Project, 2013). Similar figures are recorded for Canada (Gibson, 2014). It is not unreasonable to assume that percentages would be high in most other developed countries. The range of competencies, including health literacy, needed to evaluate the quality of health information, conduct effective information searches and evaluate the quality and trustworthiness of information sources has been underestimated for more than a decade (Ivanitskaya et al., 2006).

\section{Health Literacy}

Health literacy at its simplest is defined as: 'individuals' knowledge and skills to deal successfully with matters of health and illness' (Abel, Hofmann, Ackermann, Bucher, \& Sakarya, 2014, p. 1). A more complex definition drawn originally from the U.S. Department of Health and Human Services Healthy People 2010 report is 'the degree to which individuals have the capacity to obtain, process, and understand basic health information and services needed to make appropriate health decisions' (Britt \& Hatten, 2013, p. 2).

There is a relationship between health literacy skills and health outcomes and evidence in several studies that health literacy levels are suboptimal and disparities in literacy are increasing (Bodie \& Dutta, 2008). The 2011 European Health Literacy survey found almost half of Europeans to have limited health literacy (HLS-EU Consortium, 2011); similar levels have been identified in North America (Manafò \& Wong, 2012). Those with low literacy incur higher health care costs, use more inpatient and emergency department services and tend to have inefficient mixes of health care services (Eichler, Wieser, \& Brügger, 2009). They will also struggle to understand, or potentially misinterpret information, including DTC advertisements (Mackert \& Love, 2011).

E-health literacy is defined as the 'ability to seek, find, understand, and appraise health information from electronic sources and apply the knowledge gained to addressing or solving a health problem' (Chen \& Lee, 2014, p. 104). It is complex, being impacted by: traditional literacy and numeracy, health literacy, computer literacy, media literacy, science literacy and information literacy (Norman \& Skinner, 2006). Communication capital, i.e. the ability to discuss problems with family, friends, colleagues or wider community members is suggested 
as an additional dimension (Jeffres, Jian, \& Yoon, 2013) although this concept has not been operationalised or tested.

It is suggested that e-Health levels will change as technology changes (Collins, Currie, Bakken, Vawdrey, \& Stone, 2012). Health literacy overall is also not static, being context specific, with different knowledge and skills needed to prevent disease and maintain a healthy lifestyle versus the knowledge and skills needed to successfully navigate health services (Abel et al., 2014). There are known socio-economic differences in digital literacy (specific skills and wider competencies impacting on both time online and tasks carried out (CastañoMuñoz, 2010).

Cross country studies conducted by the OECD and other organisations identify five different levels of literacy. Level 3 is regarded as the 'minimum required for individuals to meet the complex demands of everyday life and work in the emerging knowledge-based economy' (Australian Bureau of Statistics, 2006 (reissued 2008), p. 1). Recent OECD data, shown in Table 3, indicates that a significant percentage of people across a range of OECD countries do not reach this level, imposing a barrier to the comprehension and application of healthrelated information for PE.

Table 3 Percentage of adults scoring at each proficiency level in literacy (Organisation for Economic Cooperation and Development (OECD), 2013 Table 2.1)

\begin{tabular}{|c|c|c|c|c|c|c|c|}
\hline & $\begin{array}{c}\text { Below } \\
\text { level 1\% }\end{array}$ & $\begin{array}{c}\text { Level } 1 \\
\%\end{array}$ & $\begin{array}{c}\text { Level } 2 \\
\%\end{array}$ & $\begin{array}{c}\text { Level } 3 \\
\%\end{array}$ & $\begin{array}{c}\text { Level } 4 \\
\%\end{array}$ & $\begin{array}{c}\text { Level } 5 \\
\%\end{array}$ & $\begin{array}{c}\text { Missing } \\
\%\end{array}$ \\
\hline \multicolumn{8}{|c|}{$\begin{array}{l}\text { Level Descriptors: } \\
\text { Below level 1: basic vocabulary knowledge only. } \\
\text { Level 1: Read relatively short digital or print texts to locate a single piece of information } \\
\text { Level 2: Match text and information, may require paraphrasing or low-level inferences } \\
\text { Level 3: Read dense or lengthy text, identify, interpret or evaluate one or more pieces of } \\
\text { information, disregard irrelevant or inappropriate content } \\
\text { Level 4: Integrate, interpret or synthesise information from complex or lengthy texts, } \\
\text { interpret or evaluate subtle evidence-claims or persuasive discourse } \\
\text { Level 5: Search for and integrate information across multiple dense texts, construct } \\
\text { synthesis of similar and contrasting ideas or evaluate evidence-based argument, make high- } \\
\text { level inferences } \\
\text { Note: Adults in the missing category were not able to provide enough background } \\
\text { information to impute proficiency scores because of language difficulties, learning or } \\
\text { mental disabilities }\end{array}$} \\
\hline Australia & 3.1 & 9.4 & 29.2 & 39.4 & 15.7 & 1.3 & 1.9 \\
\hline Germany & 3.3 & 14.2 & 33.9 & 36.4 & 10.2 & 0.5 & 1.5 \\
\hline Japan & 0.6 & 4.3 & 22.8 & 48.6 & 21.4 & 1.2 & 1.2 \\
\hline Norway & 3.0 & 9.3 & 30.2 & 41.6 & 13.1 & 0.6 & 2.2 \\
\hline Poland & 3.9 & 14.8 & 36.5 & 35.0 & 9.0 & 0.7 & 0.0 \\
\hline USA & 3.9 & 13.6 & 32.6 & 34.2 & 10.9 & 0.6 & 4.2 \\
\hline England & 3.3 & 13.1 & 33.1 & 36.0 & 12.4 & 0.8 & 1.4 \\
\hline $\begin{array}{l}\text { Russian } \\
\text { Fed }\end{array}$ & 1.6 & 11.5 & 34.9 & 41.2 & 10.4 & 0.4 & 0.0 \\
\hline
\end{tabular}




\section{Health Numeracy}

Closely linked to health literacy, and often regarded as a subset of it, is the concept of health numeracy - the ability to access, understand and apply numerical data in health decisions (Ancker \& Kaufman, 2007). Numeric information covers disease risks, potential outcomes of undertaking disease prevention behaviours and the risks versus benefits of specific medications or medical procedures, with the assumption that understanding of this material is unproblematic and leads to informed decisions and behaviours (Lipkus \& Peters, 2009). Table 4 indicates that similar problems exist in relation to numeracy as for literacy with similar implications for the achievement of effective PE.

As with literacy, there are concerns that low numeracy skills may adversely impact on health decisions and outcomes: 'low numeracy is pervasive and constrains informed patient choice, reduces medication compliance, impedes access to treatments, impairs risk communication (limiting prevention efforts among those most vulnerable to health problems), and, based on the scant research conducted on outcomes, appears to adversely affect medical outcomes' (Reyna et al., 2009, p. 2). It has been noted that almost $40 \%$ of patients in a cancer screening study 'reported that they found it hard or very hard to understand medical statistics' (Kiechle, Bailey, Hedlund, Viera, \& Sheridan, 2015). Further, 16\% of a highly educated sample could not correctly answer questions relating to risk magnitude (Peters, Hibbard, Slovic, \& Dieckmann, 2007). In spite of this knowledge, practical solutions are not debated in the literature.

The same OECD study from which numeracy data was obtained shows that similar problems are evident in regard to numeracy, with implications for understanding factors such as correct medication dosages and that the problem is even greater in relation to problem solving ability in technology-rich environments. 
Table 4 Percentage of adults scoring at each proficiency level in numeracy (Organisation for Economic Cooperation and Development (OECD), 2013 Table A2.5)

\begin{tabular}{|c|c|c|c|c|c|c|c|}
\hline & $\begin{array}{c}\text { Below } \\
\text { level } 1 \\
\%\end{array}$ & $\begin{array}{c}\text { Level } 1 \\
\%\end{array}$ & $\begin{array}{c}\text { Level } 2 \\
\%\end{array}$ & $\begin{array}{c}\text { Level } 3 \\
\%\end{array}$ & $\begin{array}{c}\text { Level } 4 \\
\%\end{array}$ & $\begin{array}{c}\text { Level } 5 \\
\%\end{array}$ & $\begin{array}{c}\text { Missing } \\
\%\end{array}$ \\
\hline \multicolumn{8}{|c|}{$\begin{array}{l}\text { Level 2: Perform task that require identifying and acting on mathematical information in } \\
\text { common contexts } \\
\text { Level 3: Perform task that require an understanding of mathematical information in } \\
\text { contexts that are not always familiar and are presented in more complex ways } \\
\text { Level 4: Perform tasks that may be complex, abstract or embedded in unfamiliar contexts: } \\
\text { multiple steps requiring selection of appropriate problem-solving } \\
\text { level 5: Understand complex representations and abstract and formal mathematical and } \\
\text { statistical ideas, sometimes embedded in complex texts } \\
\text { Note: Adults in the missing category were not able to provide enough background } \\
\text { information to impute proficiency scores because of language difficulties, learning or } \\
\text { mental disabilities }\end{array}$} \\
\hline Australia & 5.7 & 14.4 & 32.1 & 32.6 & 11.7 & 1.5 & 1.9 \\
\hline Germany & 4.5 & 13.9 & 31.0 & 34.9 & 13.0 & 1.2 & 1.5 \\
\hline Japan & 1.2 & 7.0 & 28.1 & 43.7 & 17.3 & 1.5 & 1.2 \\
\hline Norway & 4.3 & 10.2 & 28.4 & 37.4 & 15.7 & 1.7 & 2.2 \\
\hline Poland & 5.9 & 17.6 & 37.7 & 30.5 & 7.7 & 0.7 & 0.0 \\
\hline $\begin{array}{l}\text { United } \\
\text { States }\end{array}$ & 9.1 & 19.6 & 32.6 & 25.9 & 7.8 & 0.7 & 4.2 \\
\hline England & 6.4 & 17.8 & 33.3 & 29.8 & 10.4 & 0.9 & 1.4 \\
\hline $\begin{array}{l}\text { Russian } \\
\text { Federation }\end{array}$ & 2.0 & 12.1 & 39.7 & 38.1 & 7.7 & 0.3 & 0.0 \\
\hline
\end{tabular}

Earlier data from the Australian Bureau of Statistics indicated that, while literacy problems impacted some $40 \%$ of the population to some degree, the ability to use information to solve problems was a much more widespread problem, with up to $70 \%$ of the population having problems with problem solving, defined as goal-directed thinking and action in situations for which no routine solution is available (Australian Bureau of Statistics, 2006 (reissued 2008)). Unfortunately, this type of data is not available for other countries, but it is not unreasonable to assume that similar challenges exist across national borders.

The increase in online information in the expectation that people will be able to use it effectively is somewhat concerning, given the 2006 Australian findings and recent OECD findings, shown in Table 5, regarding proficiency in problem solving in technology-rich environments which is defined as: 'using digital technology, communications tools and networks to acquire and evaluate information, communicate with others and perform practical tasks' (Organisation for Economic Cooperation and Development (OECD), 2012, p. 5). It is suggested that an increasing reliance on Internet-based technology will widen these disparities (Dutta-Bergman, 2005): high levels of health / e-health literacy may be an enabler, but low levels will be a barrier (Hu et al., 2012). 
Table 5 Percentage of adults scoring at each proficiency level in problem solving in technology-rich environments (Organisation for Economic Cooperation and Development (OECD), 2013 Table 2.10a)

\begin{tabular}{|c|c|c|c|c|c|c|c|c|}
\hline & $\begin{array}{c}\text { Below } \\
\text { level } \\
1 \\
\%\end{array}$ & $\begin{array}{c}\text { Level } \\
\mathbf{1} \\
\%\end{array}$ & $\begin{array}{c}\text { Level } \\
2 \\
\%\end{array}$ & $\begin{array}{c}\text { Level } \\
\mathbf{3} \\
\%\end{array}$ & $\begin{array}{c}\text { No } \\
\text { computer } \\
\text { experience } \\
\%\end{array}$ & $\begin{array}{c}\text { Opted out } \\
\text { of } \\
\text { computer } \\
\text { based } \\
\text { assessment } \\
\%\end{array}$ & $\begin{array}{c}\text { Failed } \\
\text { ICT } \\
\text { core } \\
\%\end{array}$ & $\begin{array}{c}\text { Missing } \\
\%\end{array}$ \\
\hline
\end{tabular}

\section{Level descriptors}

Below level 1: perform one simple technology function only Level 1: Use of widely available and familiar technology applications: simple reasoning Level 2: Use of both generic and more specific technology applications. Some integration and inferential reasoning may be needed Level 3: Tasks require evaluating relevance and reliability of information. Integration and inferential reasoning may be needed to a large extent

Note: Adults in the missing category were not able to provide enough background information to impute proficiency scores because of language difficulties, learning or metal disabilities

\begin{tabular}{|l|r|l|l|l|r|r|l|l|}
\hline Australia & 9.2 & 28.9 & 31.8 & 6.2 & 4.0 & 13.7 & 3.5 & 2.7 \\
\hline Germany & 14.4 & 30.5 & 29.2 & 6.8 & 7.9 & 6.1 & 3.7 & 1.5 \\
\hline Japan & 7.6 & 19.7 & 26.3 & 8.3 & 10.2 & 15.9 & 10.7 & 1.3 \\
\hline Norway & 11.4 & 31.8 & 34.9 & 6.1 & 1.6 & 6.7 & 5.2 & 2.2 \\
\hline Poland & 12.0 & 19.0 & 15.4 & 3.8 & 19.5 & 23.8 & 6.5 & 0.0 \\
\hline $\begin{array}{l}\text { United } \\
\text { States }\end{array}$ & 15.8 & 33.1 & 26.0 & 5.1 & 5.2 & 6.3 & 4.1 & 4.3 \\
\hline England & 15.1 & 33.8 & 29.3 & 5.7 & 4.1 & 4.6 & 5.8 & 1.6 \\
\hline $\begin{array}{l}\text { Russian } \\
\text { Federation }\end{array}$ & 14.9 & 25.6 & 20.4 & 5.5 & 18.3 & 12.8 & 2.5 & 0.0 \\
\hline
\end{tabular}




\section{Research question:}

Given the barriers identified in relation to literacy and numeracy discussed in the preceding sections, we therefore set the following research question for a readability analysis: Are health information materials readily available online or through medical professions written at a level that would enable the majority of the population to readily understand them?

The OECD data reported in the earlier tables does not link to any form of measurement tool that enables information to be assessed against the levels identified in their reports. We therefore used a different methodology to obtain a measure of likely readability.

\section{Readability Analysis: Specific aim and methodology:}

Part A: Online information - Methodology: We used Google to search for two health and well-being topics, i.e. diet and exercise, 'then four of the most common chronic disorders, then analysed the first five results obtained for each using the SMOG readability index. This index indicates the years of formal education necessary to be able to comprehend material and was selected because it has been repeatedly validated, and because of its proven accuracy, correlation with other readability formulae and subsequent widespread use in the academic literature, primarily in the health field (Mumford, 1997; Wallace \& Lemon, 2004). It has been described as 'the gold standard readability measure'(Fitzsimmons, Michael, Hulley, \& Scott, 2010, p. 294). The method used for the SMOG calculations followed the methodology in the literature (Aldridge, 2004). SMOG calculations can be calculated manually, however, the originator (McLaughlin, 1969) of the SMOG formula has also provided an (undated) internet-based version of the calculator at http://www.harrymclaughlin.com/SMOG.htm. Thus, we compared the manually calculated results with those derived from the internet version and found no difference between them. This calculation measures only the likely reading level in terms of years of formal education required for comprehension of the material and not other aspects such as suitability of material for patient needs which could be assessed using other tools such as the Readability Assessment Instrument (RAIN) (Adkins, Elkins, \& Singh, 2001) or the Suitability Assessment of Materials measurement (SAM)(Doak, Doak, \& Root, 1985). Excluded were: dictionary definitions, sales-based sites such as for herbal weight loss or asthma relief products, sites that duplicated information such as Australian state and federal sites. In this latter instance, only the first site was used, whether state or federal in origin. Sites in languages other than English (which only occurred for one diabetes medication) and online pharmacies offering medication without prescription were also excluded.

Reading is a skill like any other and the average adult reading skill level will fall by $3-5$ grades below the level expected at the completion of formal education. Thus an adult who left school after 12 years of formal education but who does not maintain their reading skills can be expected to have a reading skill level of $7-9$ (Kemp \& Eagle, 2008). To be readily comprehended by the majority of people, we therefore would expect that the material analysed would return readability scores within the $7-9$ range. We will show that this is not in fact the case for the vast majority of the sites. As the following tables indicate, all bar two of the sites examined (WebMD in Table 6 and NHBLI in Table 9) contain material written well above the average person's ability to understand it.

It is interesting to note that Wikipedia sites in Tables 6,7 and 8 contain material that requires at least some tertiary education, and for physical exercise in Table 6, to post graduate level. 
It is of further concern that several government-funded organisations' material and that from drug information sites also present material that requires tertiary education. This probably reflects the education level of those providing the material rather than the intended users of it but indicates the need for the providers of this type of information to be more attuned to the abilities of the intended recipients of the material.

Table 6: SMOG analysis for general health and well-being Internet -based material

\begin{tabular}{|c|c|c|}
\hline Organisation & URL & SMOG \\
\hline \multicolumn{3}{|c|}{ General health and Well-being: a. Diet } \\
\hline Impromy & $\begin{array}{l}\text { http://impromy.com/?gclid=CIOEvdmh4MECFY0svQ } \\
\text { odDrUA7w }\end{array}$ & 14.91 \\
\hline Web MD & $\begin{array}{l}\text { http://www.webmd.com/diet/features/what-your- } \\
\text { parents-got-wrong-about-food }\end{array}$ & 9.04 \\
\hline Body + Soul & http://www.bodyandsoul.com.au/weight+loss/diets/ & 11.2 \\
\hline Body Trim & http://www.bodytrim.com.au/diet & 12.53 \\
\hline Wikipedia & http://en.wikipedia.org/wiki/Diet_(nutrition) & 13.46 \\
\hline The 5.2 fast diet & http://thefastdiet.co.uk/ & 9.95 \\
\hline \multicolumn{3}{|c|}{ General health and Well-being: b. Exercise } \\
\hline Wikipedia & http://en.wikipedia.org/wiki/Physical_exercise & 15.68 \\
\hline Mayo Clinic & $\begin{array}{l}\text { http://www.mayoclinic.org/healthy-living/fitness/in- } \\
\text { depth/exercise/art-20048389 }\end{array}$ & 12.07 \\
\hline Web MD & http://www.webmd.com/fitness-exercise/ & 11.0 \\
\hline Better health Channel & $\begin{array}{l}\text { http://www.betterhealth.vic.gov.au/bhcv2/bhcarticles.n } \\
\text { sf/pages/Depression_and_exercise }\end{array}$ & 14.62 \\
\hline About Health & $\begin{array}{l}\text { http://exercise.about.com/cs/cardioworkouts/a/burn300 } \\
\text { calories.htm }\end{array}$ & 12.41 \\
\hline
\end{tabular}


Table 7: SMOG analysis for general and specific medication-focussed Internet -based material for Diabetes

\begin{tabular}{|l|l|l|}
\hline Organisation & URL & SMOG \\
\hline Chronic Medical Condition: Diabetes & 12.30 \\
\hline Health Direct Australia & $\begin{array}{l}\text { http://www.healthdirect.gov.au/diabetes?gclid=CJ- } \\
\text { bvb255MECFVcDvAodrkkAdQ }\end{array}$ & 13.05 \\
\hline Wikipedia & $\underline{\text { http://en.wikipedia.org/wiki/Diabetes_mellitus }}$ & 13.14 \\
\hline Diabetes Australia & $\underline{\text { http://www.ndss.com.au/en/About-Diabetes/ }}$ & 11.93 \\
\hline About.com & $\begin{array}{l}\text { http://index.about.com/index?gclid=CNjc8bG85MECF } \\
\text { RUJvAodH74Aag\&am=broad\&q=information+about }\end{array}$ & \\
\hline $\begin{array}{l}\text { +diabetes\&an=google_s\&askid=8a623177-5e3e-4891- } \\
\text { 9676-d5558de07725-0- } \\
\text { ab_gsb\&dqi=\&qsrc=999\&ad=semD\&o=5946\&l=sem }\end{array}$ & \\
\hline American Diabetes Asn & $\underline{\text { http://www.diabetes.org/ }}$ & 13.91 \\
\hline $\begin{array}{l}\text { Diabetes-specific drugs } \\
\text { Better Health: Diabex }\end{array}$ & $\begin{array}{l}\text { http://www.betterhealth.vic.gov.au/bhcv2/bhcmed.nsf/ } \\
\text { pages/afcdiabe/\$File/afcdiabe.pdf }\end{array}$ & 13.51 \\
\hline $\begin{array}{l}\text { Virtual Medical Centre: } \\
\text { Diabex }\end{array}$ & $\underline{\text { http://www.myvmc.com/drugs/diabex/ }}$ & 12.21 \\
\hline $\begin{array}{l}\text { Livestrong: Diabex } \\
\text { side effects }\end{array}$ & $\begin{array}{l}\text { http://www.livestrong.com/article/252403-side-effects- } \\
\text { of-diabex/ }\end{array}$ & 11.18 \\
\hline $\begin{array}{l}\text { Gp2u: Diabex product } \\
\text { information }\end{array}$ & $\underline{\text { https://gp2u.com.au/static/pdf/D/DIABEX_XR-PI.pdf }}$ & 13.39 \\
\hline $\begin{array}{l}\text { My Virtual Medical } \\
\text { Centre: Glucohexal }\end{array}$ & $\underline{\text { http://www.myvmc.com/drugs/glucohexal/ }}$ & 14.10 \\
\hline
\end{tabular}

Table 8: SMOG analysis for general and specific medication-focussed Internet -based material for Asthma

\begin{tabular}{|c|c|c|}
\hline Organisation & URL & SMOG \\
\hline \multicolumn{3}{|c|}{ Chronic Medical Condition: Asthma } \\
\hline Health Direct Australia & $\begin{array}{l}\text { http://www.healthdirect.gov.au/asthma?gclid=CKihsI } \\
\text { K 5MECFQoDvAodySIAbA }\end{array}$ & 11.37 \\
\hline Wikpedia & http://en.wikipedia.org/wiki/Asthma & 14.51 \\
\hline $\begin{array}{l}\text { Royal Children's } \\
\text { Hospital }\end{array}$ & $\begin{array}{l}\text { http://www.rch.org.au/clinicalguide/guideline_index/A } \\
\text { sthma_Acute/ }\end{array}$ & 17.04 \\
\hline $\begin{array}{l}\text { Royal Children's } \\
\text { Hospital: Parent's } \\
\text { handout }\end{array}$ & http://www.rch.org.au/kidsinfo/fact_sheets/Asthma/ & 10.14 \\
\hline $\begin{array}{l}\text { National Heart, Lung } \\
\text { and Blood Institute }\end{array}$ & $\begin{array}{l}\text { http://www.nhlbi.nih.gov/health/health- } \\
\text { topics/topics/asthma/ }\end{array}$ & 7.95 \\
\hline \multicolumn{3}{|l|}{ Asthma-specific drugs } \\
\hline Drugs.com: Ventolin & http://www.drugs.com/ventolin.html & 11.39 \\
\hline $\begin{array}{l}\text { GlaxoSmith Kline: } \\
\text { Ventolin }\end{array}$ & $\begin{array}{l}\text { http://www.gsk.com.au/products_prescription- } \\
\text { medicines_detail.aspx?view=29 }\end{array}$ & 11.07 \\
\hline Better Health: Bricanyl & $\begin{array}{l}\text { http://www.betterhealth.vic.gov.au/bhcv2/bhcmed.nsf/ } \\
\text { pages/apcbrici/\$File/apcbrici.pdf }\end{array}$ & 13.52 \\
\hline Medicine.Net.com & http://www.medicinenet.com/terbutaline/article.htm & 12.32 \\
\hline $\begin{array}{l}\text { Netdoctor.co.uk: } \\
\text { Bricanyl }\end{array}$ & $\begin{array}{l}\text { http://www.netdoctor.co.uk/allergy-and- } \\
\text { asthma/medicines/bricanyl.html }\end{array}$ & 12.00 \\
\hline
\end{tabular}


Table 9: SMOG analysis for Coronary Heart Disease

\begin{tabular}{|c|c|c|}
\hline Organisation & URL & SMOG \\
\hline \multicolumn{3}{|c|}{ Chronic Medical Condition: Coronary Heart Disease } \\
\hline Health Direct & $\begin{array}{l}\text { http://www.healthdirect.gov.au/coronary-heart- } \\
\text { disease-and-atherosclerosis?gclid=Cj0KEQjw- } \\
\text { tSrBRCk8bzDiO gbwBEiQAk- } \\
\text { D31YjdFWV689JqarJP5opMZ2F29qWg0_3XNUfsw } \\
\text { yAL7pMaArdh8P8HAQ }\end{array}$ & 14.94 \\
\hline Heart Foundation & $\begin{array}{l}\text { http://www.heartfoundation.org.au/Pages/default.aspx? } \\
\text { gclid=Cj0KEQjw-tSrBRCk8bzDiO gbwBEiQAk- } \\
\text { D31cVPp0kZ6Z6z7wyYYK1P6dcbL17jKYoNdy0Wt } \\
\text { LE5RyMaApUP8P8HAQ }\end{array}$ & 12.78 \\
\hline $\begin{array}{l}\text { Heart Research } \\
\text { Institute }\end{array}$ & http://www.hri.org.au/Page.aspx?pid=351 & 13.17 \\
\hline $\begin{array}{l}\text { US National Heart, } \\
\text { Lung, and Blood } \\
\text { Institute }\end{array}$ & $\begin{array}{l}\text { http://www.nhlbi.nih.gov/health/health- } \\
\text { topics/topics/cad }\end{array}$ & 10.10 \\
\hline Wikipedia & http://en.wikipedia.org/wiki/Coronary_artery_disease & 11.98 \\
\hline \multicolumn{3}{|c|}{ Heart disease - specific drugs } \\
\hline $\begin{array}{l}\text { Web MD ACE } \\
\text { Inhibitors }\end{array}$ & $\begin{array}{l}\text { http://www.webmd.com/heart-disease/tc/coronary- } \\
\text { artery-disease-medications }\end{array}$ & 11.30 \\
\hline $\begin{array}{l}\text { Mayo Clinic } \\
\text { Cholesterol- modifying } \\
\text { medication }\end{array}$ & $\begin{array}{l}\text { http://www.mayoclinic.org/diseases- } \\
\text { conditions/coronary-artery- } \\
\text { disease/basics/treatment/con-20032038 }\end{array}$ & 13.06 \\
\hline $\begin{array}{l}\text { NHS Choices } \\
\text { Antiplatelets low dose } \\
\text { asprin } \\
\text { Antiplatelets } \\
\text { clopidogrel }\end{array}$ & $\begin{array}{l}\text { http://www.nhs.uk/conditions/Anti-platelets-aspirin- } \\
\text { low-dose-/Pages/Introduction.aspx }\end{array}$ & 14.87 \\
\hline Drugs.com Norvasc & $\begin{array}{l}\text { http://www.drugs.com/condition/coronary-artery- } \\
\text { disease.html }\end{array}$ & 10.52 \\
\hline $\begin{array}{l}\text { Medicine.Net } \\
\text { Betablockers }\end{array}$ & http://www.medicinenet.com/beta_blockers/article.htm & 15.09 \\
\hline $\begin{array}{l}\text { Mayoclinic } \\
\text { Betablockers }\end{array}$ & $\begin{array}{l}\text { http://www.mayoclinic.org/diseases-conditions/high- } \\
\text { blood-cholesterol/in-depth/statins/art-20045772 }\end{array}$ & 11.47 \\
\hline
\end{tabular}


Table 10: SMOG analysis for Alzheimer's Disease

\begin{tabular}{|c|c|c|}
\hline Organisation & URL & SMOG \\
\hline \multicolumn{3}{|c|}{ Chronic Medical Condition: Alzheimer's Disease } \\
\hline Health Direct & $\begin{array}{l}\text { http://www.healthdirect.gov.au/alzheimers- } \\
\text { disease?gclid=Cj0KEQjw- } \\
\text { tSrBRCk8bzDiO gbwBEiQAk- } \\
\text { D31dz5ieWx21uno9AcAHQAN4qC7jBaFFxMoC03- } \\
\text { 9kUkuMaAiTm8P8HAQ }\end{array}$ & 14.55 \\
\hline Fight Dementia.org & $\begin{array}{l}\text { https://fightdementia.org.au/about-dementia-and- } \\
\text { memory-loss/about-dementia/types-of- } \\
\text { dementia/alzheimers-disease }\end{array}$ & 13.84 \\
\hline Wikipedia & http://en.wikipedia.org/wiki/Alzheimer's_disease & 13.39 \\
\hline $\begin{array}{l}\text { National Institute on } \\
\text { Aging }\end{array}$ & $\begin{array}{l}\text { https://www.nia.nih.gov/alzheimers/publication/alzhei } \\
\text { mers-disease-fact-sheet }\end{array}$ & 13.17 \\
\hline Better Health Channel & $\begin{array}{l}\text { http://www.betterhealth.vic.gov.au/bhcv2/bhcarticles.n } \\
\text { sf/pages/Dementia_-_Alzheimer's_disease }\end{array}$ & 14.33 \\
\hline \multicolumn{3}{|c|}{ Alzheimer-specific drugs } \\
\hline $\begin{array}{l}\text { National Institute on } \\
\text { Aging }\end{array}$ & $\begin{array}{l}\text { https://www.nia.nih.gov/alzheimers/publication/alzhei } \\
\text { mers-disease-medications-fact-sheet }\end{array}$ & 15.25 \\
\hline Donepezil (Aricept) & http://www.aricept.com/ & 13.49 \\
\hline $\begin{array}{l}\text { Galantamine } \\
\text { (Razadyne) }\end{array}$ & $\begin{array}{l}\text { http://www.nlm.nih.gov/medlineplus/druginfo/meds/a } \\
\text { 699058.html }\end{array}$ & 10.16 \\
\hline Rivastigmine (Exelon) & http://www.rxlist.com/exelon-drug.htm & 13.02 \\
\hline $\begin{array}{l}\text { Namenda (memantine } \\
\mathrm{HCl} \text { ) }\end{array}$ & http://www.namenda.com/ & 13.09 \\
\hline
\end{tabular}


Part B: We then analysed a range of standard patient information leaflets available from a general medical practice and obtained similar findings to the Internet-based material as shown in Table 11. While the readability scores are lower than the Internet-based material, a significant percentage of the population are likely to still struggle with comprehension of this material. Once again, this is a potential barrier to effective PE.

Table 11 SMOG analysis for Australian patient information leaflets

\begin{tabular}{|l|l|c|}
\hline Organisation & Leaflet title & SMOG \\
\hline Chronic Medical Condition: & 13.83 \\
\hline $\begin{array}{l}\text { National Diabetes } \\
\text { Support Service }\end{array}$ & Live well with Diabetes Join the NDSS leaflet \\
\hline $\begin{array}{l}\text { National Diabetes } \\
\text { Support Service }\end{array}$ & Living Well with Diabetes & 9.51 \\
\hline $\begin{array}{l}\text { Townsville Health } \\
\text { Service District }\end{array}$ & 'More About Diabetes' Group & 12.87 \\
\hline Asthma Australia & Asthma Care & 9.79 \\
\hline $\begin{array}{l}\text { Boehringer Ingelheim } \\
\text { Pharmaceuticals }\end{array}$ & Managing COPD with SPIRIVA & 11.31 \\
\hline $\begin{array}{l}\text { Pfizer / Quit Victoria } \\
\text { (joint initiative with } \\
\text { several health } \\
\text { organisations }\end{array}$ & Champix can help you quit smoking & 11.06 \\
\hline
\end{tabular}

It is therefore evident that the majority of the material analysed both from Internet-based and more 'traditional' sources is written in language far too complex for the average person to understand and thus act on, thus presenting a major impediment to the achievement of effective PE. Given that PE is, as we noted earlier, a public policy strategy and that a large amount of material originates from sources either directly or indirectly funded by government, this issue could be readily addressed

\section{Discussion and Conclusions}

The concept of effective patient empowerment faces multiple challenges, particularly in relation to information provision, comprehension and use. The concept, together with its potential barriers and enablers, needs to be mapped in much more detail than has been achieved to date. As part of this, sophisticated analytical research is needed in a number of areas in order to expand and considerably strengthen the currently weak theoretical foundations in the area. As we notes earlier, Uses and Gratification Theory indicates that if patients do not gain information that meets their needs, they will seek information from other sources. What is not known is what these sources might then be, and how information from combinations of sources are used and with what outcomes for PE and ultimately for the patients themselves. Given that the resources reviewed are unlikely to meet the needs of a significant percentage of populations, this issue should be explored as a priority.

As part of this, persuasive health communications should be viewed holistically rather than focussing on individual sectors such as DTC / DTCA, with a greater understanding of the social and cultural factors that impact on whether, how and from what sources information is sought, interpreted and acted upon. Coupled with this should be a focus on the implications of literacy limitations and the implications for user comprehension together with how existing information can be revised, or alternative sources provided. It is important for all sectors of the health information community, from pharmaceutical companies through to health care 
providers and those managing online support groups and policy makers to recognise these challenges and to integrate patient use of web-based information into optimum health decision making and to recognise the role and relative importance of all information sources.

\section{Limitations of this study}

Only a small range of medical conditions and websites were analysed, however as these were the first to be listed during the search processes, it is likely that they will be visited first by those seeking information. A wider range of sites may also have identified 'alternative' treatment options.

It would also have been desirable to have linked the OECD data directly to readability but no measurement tool exists for this. We believe that the use of the widely used and wellvalidated SMOG index is an appropriate alternative.

\section{Directions for future research}

This research will be extended to include a wider range of medical conditions and of potential information sources, including online discussion and support groups, including social networking sites as well as phone apps. It will also seek to identify the combination of media channels used to gain information about treatment options by patients, with a specific emphasis on new and social media forms, and assess the extent to which these channels influence patients' interactions with health professionals and, ultimately, health decisions as well as satisfaction and health outcome measures.

Further avenues for future research include evaluation of differences in behaviour and information seeking based on health literacy and education levels, consistent with van Deursen \& van Dijks (2014) observation that accessing of information sources on the Internet is mediated by education and socio-economic factors. Following on from this, potentially fruitful research should explore how recipients of Internet-based information react towards information written at a level different to their personal health literacy level. This will be followed by exploration of how differing formats of both text-based and numerical information impact on comprehension and application to health decisions across population segments and different levels of certainty / uncertainty regarding potential decision outcomes.

In addition, dialogue with those providing health information resources would be useful in order to test the impact of changes in readability on patient outcomes.

\section{References}

Abel, T., Hofmann, K., Ackermann, S., Bucher, S., \& Sakarya, S. (2014). Health literacy among young adults: a short survey tool for public health and health promotion research. Health Promotion International, dat096.

Acosta-Deprez, V., Erlyana, E., Sinay, T., O'Lawrence, H., Jacot, E., Ramirez, J., \& Shim, K. Y. (2013). Factors Influencing Health Information Seeking Behaviors of Internet Users. Paper presented at the World Conference on E-Learning in Corporate, Government, Healthcare, and Higher Education.

Adkins, A., Elkins, E., \& Singh, N. (2001). Readability of NIHM East-to-read Patient Education Materials. Journal of Child and Family Studies, 10(3), 279 - 285.

Ahn, H.-Y. A., Park, J. S., \& Haley, E. (2014). Consumers' Optimism Bias and Responses to Risk Disclosures in Direct-to-Consumer (DTC) Prescription Drug Advertising: The Moderating Role of Subjective Health Literacy. Journal of Consumer Affairs, 48(1), 175-194. 
Aldridge, M. (2004). Writing and Designing Readable Patient Education Materials. Nephrology Nursing Journal, 31(4), 373 - 377.

Ancker, J. S., \& Kaufman, D. (2007). Rethinking health numeracy: A multidisciplinary literature review. Journal of the American Medical Informatics Association, 14(6), 713-721.

Australian Bureau of Statistics. (2006 (reissued 2008)). Adult Literacy and Life Skill Survey. Retrieved from Canberra: http://www.letsread.com.au/getmedia/96e0d766-38214878-a3bb-e9b41c01d347/ABS-2006.pdf.aspx

Ball, J. G., Liang, A., \& Lee, W.-N. (2014). Potential for Stigma Reduction Through Directto-Consumer Prescription Drug Advertising: An Exploratory Content Analysis of Television Commercials. Journal of Current Issues \& Research in Advertising, 35(2), 190-208.

Bartlett, Y. K., \& Coulson, N. S. (2011). An investigation into the empowerment effects of using online support groups and how this affects health professional/patient communication. Patient Education and Counseling, 83(1), 113-119.

Beaudoin, C. E., \& Tao, C.-C. (2007). Benefiting from social capital in online support groups: An empirical study of cancer patients. CyberPsychology \& Behavior, 10(4), 587-590.

Bell, R. A., Hu, X., Orrange, S. E., \& Kravitz, R. L. (2011). Lingering questions and doubts: Online information-seeking of support forum members following their medical visits. Patient Education and Counseling, 85(3), 525-528.

Black, A. D., Car, J., Pagliari, C., Anandan, C., Cresswell, K., Bokun, T., . . Sheikh, A. (2011). The impact of eHealth on the quality and safety of health care: a systematic overview. PLoS Medicine, 8(1), e1000387.

Bodie, G. D., \& Dutta, M. J. (2008). Understanding health literacy for strategic health marketing: eHealth literacy, health disparities, and the digital divide. Health marketing quarterly, 25(1-2), 175-203.

Bowes, P., Stevenson, F., Ahluwalia, S., \& Murray, E. (2012). 'I need her to be a doctor': patients' experiences of presenting health information from the internet in GP consultations. British Journal of General Practice, 62(604), e732-e738.

Britt, R. K., \& Hatten, K. N. (2013). Need for Cognition and Electronic Health Literacy and Subsequent Information Seeking Behaviors Among University Undergraduate Students. SAGE Open, 3(4), 2158244013508957.

Calvillo, J., Román, I., \& Roa, L. M. (2013). How technology is empowering patients? A literature review. Health Expectations.

Castaño-Muñoz, J. (2010). Digital inequality among university students in developed countries and its relation to academic performance. RUSC. Universities and Knowledge Society Journal, 7(1).

Chen, W., \& Lee, K.-H. (2014). More than search? Informational and participatory eHealth behaviors. Computers in Human Behavior, 30, 103-109.

Chen, W., Lee, K. H., Straubhaar, J. D., \& Spence, J. (2014). Getting a second opinion: Social capital, digital inequalities, and health information repertoires. Journal of the Association for Information Science and Technology.

Choi, S., \& Lee, W.-N. (2007). Understanding the Impact of Direct-to-Consumer (DTC) Pharmaceutical Advertising on Patient-Physician Interactions: Adding the Web to the Mix. Journal of Advertising, 36(3), 137-149. Retrieved from http://search.ebscohost.com/login.aspx?direct=true $\& \mathrm{db}=$ eoah \&AN=12736477\&site=e host-live

Collier, R. (2014). Patient engagement or social media marketing? CMAJ: Canadian Medical Association journal= journal de l'Association medicale canadienne, 186(8), E237. 
Collins, S. A., Currie, L. M., Bakken, S., Vawdrey, D. K., \& Stone, P. W. (2012). Health literacy screening instruments for eHealth applications: a systematic review. Journal of Biomedical Informatics, 45(3), 598-607.

Dave, D., \& Saffer, H. (2012). Impact of direct-to-consumer advertising on pharmaceutical prices and demand. Southern Economic Journal, 79(1), 97-126.

Doak, C., Doak, L., \& Root, J. (1985). Teaching Patients with Low Literacy Skills. Philadelphia, Pa.: Lippincott.

Donohue, J. M., Cevasco, M., \& Rosenthal, M. B. (2007). A decade of direct-to-consumer advertising of prescription drugs. New England journal of medicine, 357(7), 673-681.

Dutta-Bergman, M. J. (2005). Access to the Internet in the context of community participation and community satisfaction. New Media \& Society, 7(1), 89-109.

Eagle, L. C., \& Chamberlain, K. C. (2004). Prescription Medicine Advertising: Professional Discomfort and Potential Patient Benefits - Can the Two be Balanced? International Journal of Advertising, 23(1), 69 - 90.

Ebi, K. L., \& Semenza, J. C. (2008). Community-Based Adaptation to the Health Impacts of Climate Change. American Journal of Preventive Medicine, 35(5), 501-507.

Retrieved from http://linkinghub.elsevier.com/retrieve/pii/S0749379708006843?showall=true

Egger, G. J., Binns, A. F., \& Rossner, S. R. (2009). The emergence of" lifestyle medicine" as a structured approach for management of chronic disease. Medical Journal of Australia, 190(3), 143.

Eichler, K., Wieser, S., \& Brügger, U. (2009). The costs of limited health literacy: a systematic review. International Journal of Public Health, 54(5), 313-324. doi:10.1007/s00038-009-0058-2

Feste, C., \& Anderson, R. M. (1995). Empowerment: from philosophy to practice. Patient Education and Counseling, 26(1), 139-144.

Finlayson, G. (2005). Direct-to-consumer Advertising of Prescription Drugs: Help or Hindrance to the Public's Health. Journal of Consumer Marketing, 22(7), 429 - 431.

Fitzsimmons, P., Michael, B., Hulley, J., \& Scott, G. (2010). A readability assessment of online Parkinson's disease information. The journal of the Royal College of Physicians of Edinburgh, 40(4), 292.

Fogel, J., \& Teichman, C. (2014). Variables Associated With Seeking Information From Doctors and the Internet After Exposure to Direct-to-Consumer Advertisements for Prescription Medications. Health marketing quarterly, 31(2), 150-166.

Gaag, M., \& Webber, M. (2008). Measurement of Individual Social Capital

In I. Kawachi, S. V. Subramanian, \& D. Kim (Eds.), Social Capital and Health (pp. 29-49): Springer New York.

Gibson, S. (2014). Regulating Direct-to-Consumer Advertising of Prescription Drugs in the Digital Age. Laws, 3(3), 410-438.

Gilbert, D., Walley, T., \& New, B. (2000). Lifestyle medicines. BMJ, 321(7272), 1341-1344. Retrieved from http://www.ncbi.nlm.nih.gov/entrez/query.fcgi?cmd=Retrieve \&db=PubMed\&dopt=Ci tation\&list_uids $=11090522$

Greene, J., \& Hibbard, J. H. (2012). Why does patient activation matter? An examination of the relationships between patient activation and health-related outcomes. Journal of General Internal Medicine, 27(5), 520-526.

Greene, J. A., \& Kesselheim, A. S. (2010). Pharmaceutical marketing and the new social media. New England journal of medicine, 363(22), 2087-2089. 
Gu, P., Williams, K. A., Aslani, P., \& Chaar, B. B. (2011). Direct-to-consumer advertising of prescription medicines on the internet: An Australian consumer perspective. Journal of Pharmacy Practice and Research, 41(3), 196.

HLS-EU Consortium. (2011). Comparative Report of health Literacy in Eight EU Member States. . Retrieved from Maastricht:

Hou, J., \& Shim, M. (2010). The role of provider-patient communication and trust in online sources in Internet use for health-related activities. Journal of Health Communication, 15(sup3), 186-199.

Hu, X., Bell, R. A., Kravitz, R. L., \& Orrange, S. (2012). The prepared patient: information seeking of online support group members before their medical appointments. Journal of Health Communication, 17(8), 960-978.

Hughes, B., Joshi, I., \& Wareham, J. (2008). Health 2.0 and Medicine 2.0: tensions and controversies in the field. Journal of Medical Internet Research, 10(3), e23-e23. Retrieved from http://search.ebscohost.com/login.aspx?direct=true \&db=cmedm\&AN=18682374\&site =ehost-live

Ivanitskaya, L., O’Boyle, I., \& Casey, A. M. (2006). Health information literacy and competencies of information age students: results from the interactive online Research Readiness Self-Assessment (RRSA). Journal of Medical Internet Research, 8(2).

Iwase, T., Suzuki, E., Fujiwara, T., Takao, S., Doi, H., \& Kawachi, I. (2012). Do bonding and bridging social capital have differential effects on self-rated health? A community based study in Japan. Journal of Epidemiology and Community Health, 66(6), 557562.

Jeffres, L. W., Jian, G., \& Yoon, S. (2013). Conceptualizing Communication Capital for a Changing Environment. Communication Quarterly, 61(5), 539-563.

Joosten, E., DeFuentes-Merillas, L., De Weert, G., Sensky, T., Van Der Staak, C., \& de Jong, C. A. (2008). Systematic review of the effects of shared decision-making on patient satisfaction, treatment adherence and health status. Psychotherapy and psychosomatics, 77(4), 219-226.

Kaphingst, K. A., Kreuter, M. W., Casey, C., Leme, L., Thompson, T., Cheng, M.-R., . . Filler, C. (2012). Health literacy index: Development, reliability, and validity of a new tool for evaluating the health literacy demands of health information materials. Journal of Health Communication, 17(sup3), 203-221.

Kemp, G., \& Eagle, L. (2008). Shared meanings or missed opportunities? The implications of functional health literacy for social marketing interventions. International Review on Public and Nonprofit Marketing, 5(2), 117-128. Retrieved from http://search.ebscohost.com/login.aspx?direct=true $\& \mathrm{db}=\mathrm{eoah} \& \mathrm{AN}=17311219 \&$ site $=\mathrm{e}$ host-live

Kiechle, E. S., Bailey, S. C., Hedlund, L. A., Viera, A. J., \& Sheridan, S. L. (2015). Different Measures, Different Outcomes? A Systematic Review of Performance-Based versus Self-Reported Measures of Health Literacy and Numeracy. Journal of General Internal Medicine, 1-9.

Kitchens, B., Harle, C. A., \& Li, S. (2014). Quality of health-related online search results. Decision Support Systems, 57, 454-462.

Kochen, S., \& Córdoba, M. (2013). Disease Mongering in Neurological Disorders. Journal of Applied Medical Sciences, 2(4), 27-33.

Kornfield, R., Donohue, J., Berndt, E. R., \& Alexander, G. C. (2013). Promotion of prescription drugs to consumers and providers, 2001-2010. PloS one, 8(3), e55504. 
Kravitz, R. L., \& Bell, R. A. (2013). Media, messages, and medication: strategies to reconcile what patients hear, what they want, and what they need from medications. BMC medical informatics and decision making, 13(Suppl 3), S5.

Lau, A., Gabarron, E., Fernandez-Luque, L., \& Armayones, M. (2012). Social media in health-what are the safety concerns for health consumers? Health Information Management Journal, 41(2), 30.

Lee, C.-J. (2008). Does the internet displace health professionals? Journal of Health Communication, 13(5), 450-464.

Lee, C.-j., Gray, S. W., \& Lewis, N. (2010). Internet use leads cancer patients to be active health care consumers. Patient Education and Counseling, 81, S63-S69.

Lewis, N., \& Martinez, L. S. (2014). Does the Number of Cancer Patients' Close Social Ties Affect Cancer-Related Information Seeking Through Communication Efficacy? Testing a Mediation Model. Journal of Health Communication(ahead-of-print), 1-22.

Li, N., Orrange, S., Kravitz, R. L., \& Bell, R. A. (2014). Reasons for and predictors of patients' online health information seeking following a medical appointment. Family practice, June 24, $1-7$.

Lipkus, I. M., \& Peters, E. (2009). Understanding the role of numeracy in health: proposed theoretical framework and practical insights. Health Education \& Behavior, 36(6), 1065-1081.

Liu, Q., \& Gupta, S. (2011). The impact of direct-to-consumer advertising of prescription drugs on physician visits and drug requests: empirical findings and public policy implications. International Journal of Research in Marketing, 28(3), 205-217.

Mackert, M., \& Love, B. (2011). Educational content and health literacy issues in direct-toconsumer advertising of pharmaceuticals. Health marketing quarterly, 28(3), 205218.

Manafò, E., \& Wong, S. (2012). Assessing the ehealth literacy skills of older adults: a preliminary study. Journal of Consumer Health On the Internet, 16(4), 369-381.

Mano, R. S. (2014). Social media and online health services: A health empowerment perspective to online health information. Computers in Human Behavior, 39, 404-412.

Mao, J. J., Chung, A., Benton, A., Hill, S., Ungar, L., Leonard, C. E., . . Holmes, J. H. (2013). Online discussion of drug side effects and discontinuation among breast cancer survivors. Pharmacoepidemiology and drug safety, 22(3), 256-262.

Massey, P. M. (2013). Adoption and Use of Internet Technologies in Health Communication: Examining Disparities in Diffusion Patterns, Health Information Sources, and Patient-Provider Encounters. UCLA, Los Angeles.

McKinlay, J. B., Trachtenberg, F., Marceau, L. D., Katz, J. N., \& Fischer, M. A. (2014). Effects of patient medication requests on physician prescribing behavior: results of a factorial experiment. Medical care, 52(4), 294-299.

McLaughlin, G. H. (1969). SMOG Grading: A new Readability Formula. Journal of Reading, 12(8), 639 - 646. Retrieved from http://webpages.charter.net/ghal/SMOG.html

Mehta, A., \& Purvis, S. C. (2003). Consumer response to print prescription drug advertising. Journal of Advertising Research, 43(02), 194-206.

Miller, L. M. S., \& Bell, R. A. (2012). Online Health Information Seeking The Influence of Age, Information Trustworthiness, and Search Challenges. Journal of aging and health, 24(3), 525-541.

Monteith, S., Glenn, T., \& Bauer, M. (2013). Searching the internet for health information about bipolar disorder: some cautionary issues. International Journal of Bipolar Disorders, 1(1), 1-6. 
Moorhead, S. A., Hazlett, D. E., Harrison, L., Carroll, J. K., Irwin, A., \& Hoving, C. (2013). A new dimension of health care: systematic review of the uses, benefits, and limitations of social media for health communication. Journal of Medical Internet Research, 15(4).

Mowlabocus, S., Harbottle, J., Dasgupta, R., \& Haslop, C. (2014). Reaching out online: digital literacy and the uses of social media in health promotion. Working Papers of the Communities \& Culture Network+, 3, 1-24.

Moynihan, R., Heath, I., \& Henry, D. (2002). Selling sickness: the pharmaceutical industry and disease mongering. BMJ, 324(7342), 886-891. Retrieved from http://www.ncbi.nlm.nih.gov/entrez/query.fcgi?cmd=Retrieve \&db=PubMed\&dopt=Ci tation\&list_uids $=11950740$

Mumford, M. E. (1997). A Descriptive Study of the Readability of Patient Information Leaflets Designed By Nurses. Journal of Advanced Nursing, 26(5), 985-991.

Murayama, H., Fujiwara, Y., \& Kawachi, I. (2012). Social capital and health: a review of prospective multilevel studies. Journal of Epidemiology, 22(3), 179-187.

Myers, S. D., Royne, M. B., \& Deitz, G. D. (2011). Direct-to-consumer advertising: Exposure, behavior, and policy implications. Journal of Public Policy \& Marketing, 30(1), 110-118.

Norman, C. D., \& Skinner, H. A. (2006). eHealth literacy: essential skills for consumer health in a networked world. Journal of Medical Internet Research, 8(2).

Nutbeam, D. (2008). The evolving concept of health literacy. Social Science \& Medicine, 67(12), 2072-2078. doi:10.1016/j.socscimed.2008.09.050

Organisation for Economic Cooperation and Development (OECD). (2012). Literacy, Numeracy and Problem Solving in Technology-Rich Environments Framework for the OECD survey of Adult Skills. Retrieved from Paris:

Organisation for Economic Cooperation and Development (OECD). (2013). OECD Skills Outlook. Retrieved from Paris:

Peters, E., Hibbard, J., Slovic, P., \& Dieckmann, N. (2007). Numeracy skill and the communication, comprehension, and use of risk-benefit information. Health Affairs, 26(3), 741-748.

Pew Research Internet Project. (2013). Health Fact Sheet. Retrieved from http://www.pewinternet.org/fact-sheets/health-fact-sheet/

Politi, M. C., Han, P. K., \& Col, N. F. (2007). Communicating the uncertainty of harms and benefits of medical interventions. Medical Decision Making, 27(5), 681-695.

Prigge, J.-K., Dietz, B., Homburg, C., Hoyer, W. D., \& Burton, J. L. (2015). Patient empowerment: A cross-disease exploration of antecedents and consequences. International Journal of Research in Marketing.

Reyna, V. F., Nelson, W. L., Han, P. K., \& Dieckmann, N. F. (2009). How numeracy influences risk comprehension and medical decision making. Psychological Bulletin, 135(6), 943 - 973.

Sabatini, F. (2009). Social capital as social networks: A new framework for measurement and an empirical analysis of its determinants and consequences. Journal of SocioEconomics, 38(3), 429-442. doi:10.1016/j.socec.2008.06.001

Schulz, P. J., \& Nakamoto, K. (2013a). Health literacy and patient empowerment in health communication: the importance of separating conjoined twins. Patient Education and Counseling, 90(1), 4-11.

Schulz, P. J., \& Nakamoto, K. (2013b). Patient behavior and the benefits of artificial intelligence: The perils of "dangerous" literacy and illusory patient empowerment. Patient Education and Counseling, 92(2), 223-228. 
Spurgeon, D. (1999). Doctors Feel Pressurised by Direct to Consumer Advertising. British Medical Journal, 319, 1321.

Tustin, N. (2010). The role of patient satisfaction in online health information seeking. Journal of Health Communication, 15(1), 3-17.

Ventola, C. L. (2011). Direct-to-consumer pharmaceutical advertising: therapeutic or toxic? Pharmacy and Therapeutics, 36(10), 669.

Wallace, L., \& Lemon, E. (2004). American Academy of Family Physicians Patient Education Materials: Can Patients Read Them? Family Medicine Journal, 36(8), 571 -575 . 